\title{
INHIBITION OF THE EFFECT OF OXYTOCIN BY METHOXYFLURANE IN VITRO
}

Per H. Rosenberg, M.D.

DESPITE its low vapour pressure and high solubility, ${ }^{1-3}$ together with occasional nephrotoxic ${ }^{4-6}$ and hepatotoxic ${ }^{7,8}$ effects, methoxyflurane is still widely used while waiting for new and better inhalation anaesthetics.

It has, however, been considered safe and effective in obstetrical anaesthesia and analgesia ${ }^{9-12}$ and is often used with good results as a self-administered inhalation analgesic during labour. ${ }^{13-15}$ Methoxyflurane is not known to interfere with uterine contractions ${ }^{10,16}$ and no postpartum bleeding, like that seen with halothane anaesthesia ${ }^{17,18}$ has been noted. The future of methoxyflurane seems therefore to be in the field of obstetrics and consequently it was thought worthwhile to study the effect of this fluorinated inhalation anaesthetic on oxytocin activity.

\section{METHOD}

The rat uterus preparation used was basically that described for the biological assay of oxytocin in Pharmacopoea Nordica. ${ }^{19}$

Female albino Sprague-Dawley rats, in nonoestrus or in the third trimester of pregnancy (near-term), weighing 150-180 g, were killed by decapitation and one horn of the uterus was suspended in a bath containing sodium chloride $9.0 \mathrm{~g}$, potassium chloride $0.42 \mathrm{~g}$, calcium chloride $0.06 \mathrm{~g}$, sodium bicarbonate $0.5 \mathrm{~g}$, glucose $0.5 \mathrm{~g}$ and distilled water to $1000 \mathrm{ml}$. The temperature of the bath was $28-32^{\circ} \mathrm{C}$, sufficient to abolish spontaneous uterine contractions. The solution was oxygenated with air, and the contractions of the muscle were recorded on a kymograph using an isotonic and linear lever.

Oxytocin (Synthetic oxytocin, Syntocinon ${ }^{\circledR}$, Sandoz) was added to the $10 \mathrm{ml}$ bath containing the uterine horn at intervals of 3.5 minutes to allow for recovery.

Methoxyflurane (Penthrane ${ }^{\circledR}$, Abbott), halothane (Fluothan ${ }^{\circledR}$, ICI) and fluroxene (Fluoromar ${ }^{\circledR}$, Ohio Medical Products) were administered undiluted with microsyringes directly into the bottom of the bath, and were considered to be evenly mixed by the stream of air bubbles. The anaesthetics were given either one minute before or together with oxytocin.

\section{REsults}

Methoxyflurane added in doses of $0.9 \mu$ moles inhibited uterine contraction stimulated by $0.001 \mathrm{IU}$ oxytocin by about 40 per cent (Figure 1, Figure 2), as

Department of Pharmacology, University of Helsinki, Helsinki, Finland.

Correspondence: Department of Pharmacology, University of Helsinki, Siltavuorenpenger 10, 00170 Helsinki 17, Finland. 


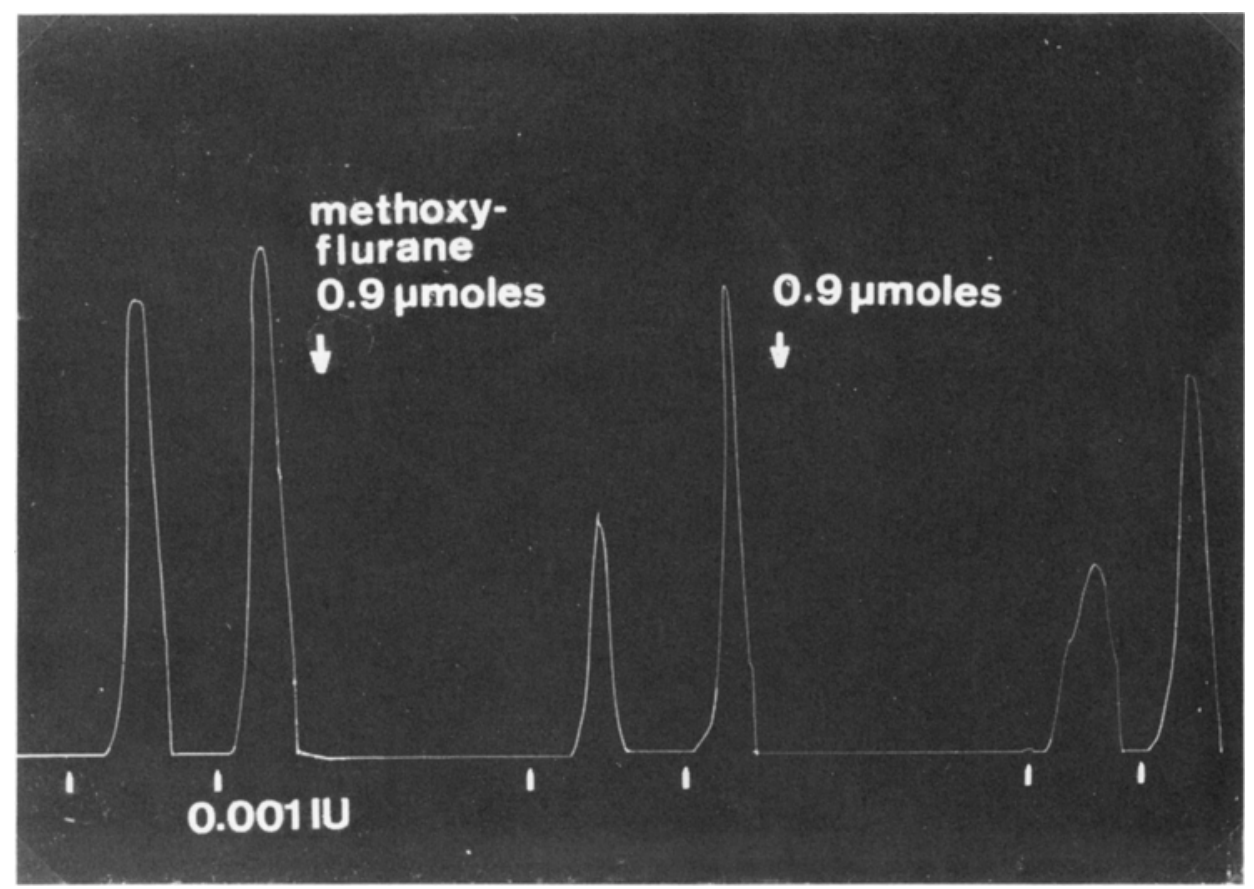

Frgure 1. Effect of $0.9 \mu$ moles of methoxyflurane on rat uterus (nonoestrus) contractions stimulated by oxytocin 0.001 IU and 0.01 IU (small arrows). Methoxyflurane was added one minute before oxytocin and the medium $(10 \mathrm{ml})$ was replaced after each contraction. The test proceeds from left to right.

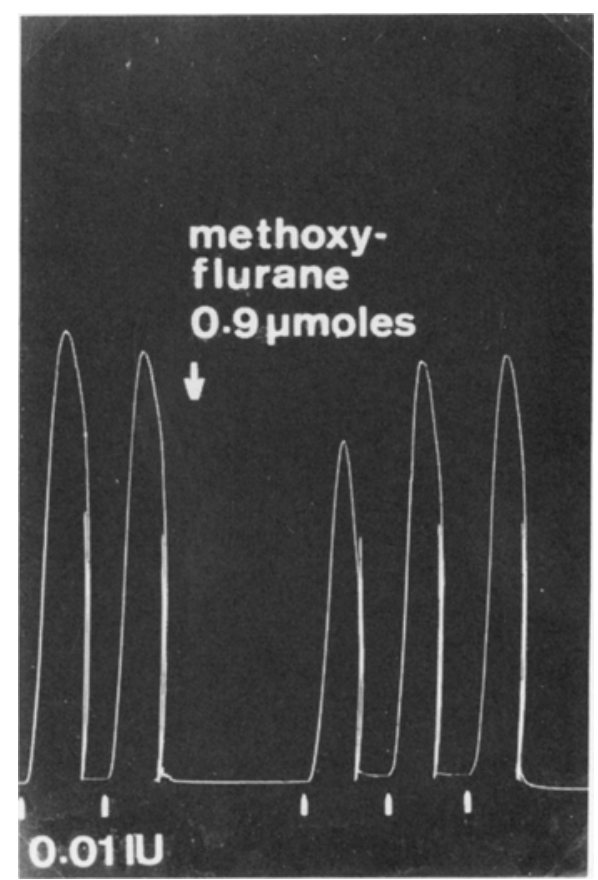




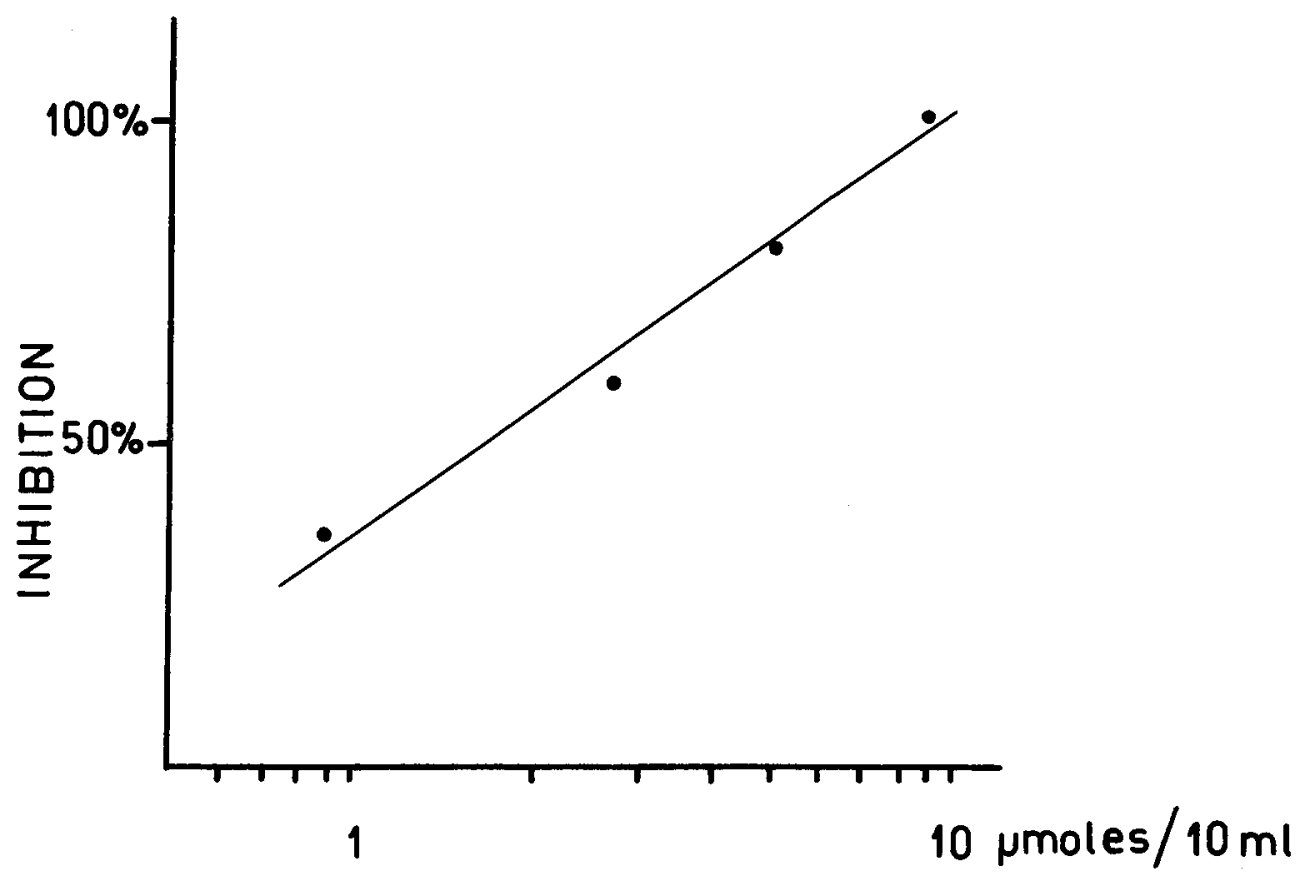

Figure 2. Inhibitory effect of increasing concentrations of methoxyflurane (logarithmic scale) on rat uterus (nonoestrus) contractions stimulated by oxytocin 0.001 IU. The percentages of inhibition are means of the effect on six different uteri.

judged by the reduction of the height of contractions. When $0.01 \mathrm{IU}$ oxytocin was used in different preparations the inhibition was only about 10 per cent. The inhibition of the stimulated contractions increased with increasing concentrations of methoxyflurane (Figure 2). Addition of $9 \mu$ moles of methoxyflurane abolished all signs of uterine activity. To obtain an inhibition of about 40 per cent of the contractions when methoxyflurane and 0.001 IU oxytocin were administered together, a dose of $4.5 \mu$ moles of the anaesthetic was needed.

There was no difference in the effect on the uteri of near-term pregnant rats, although the abolition of spontaneous uterine activity usually took a longer time than with nonpregnant uteri.

Halothane in doses of $7 \mu$ moles did not cause any inhibition of the contractions stimulated by 0.001 IU oxytocin, while $14 \mu$ moles of halothane caused approximately 50 per cent inhibition (Figure 3 ).

Fluroxene in doses of $45 \mu$ moles did not inhibit the contractions stimulated by either 0.001 or 0.01 IU oxytocin. Doses of $90 \mu$ moles inhibited the contractions stimulated by 0.001 IU oxytocin by $10-40$ per cent and those stimulated by 0.01 IU by about 25 per cent (Figure 4 ).

\section{Discussion}

There seemed to be a clear difference in the degree of inhibition exerted on oxytocin activity by these anaesthetics. All three have been considered to provide 


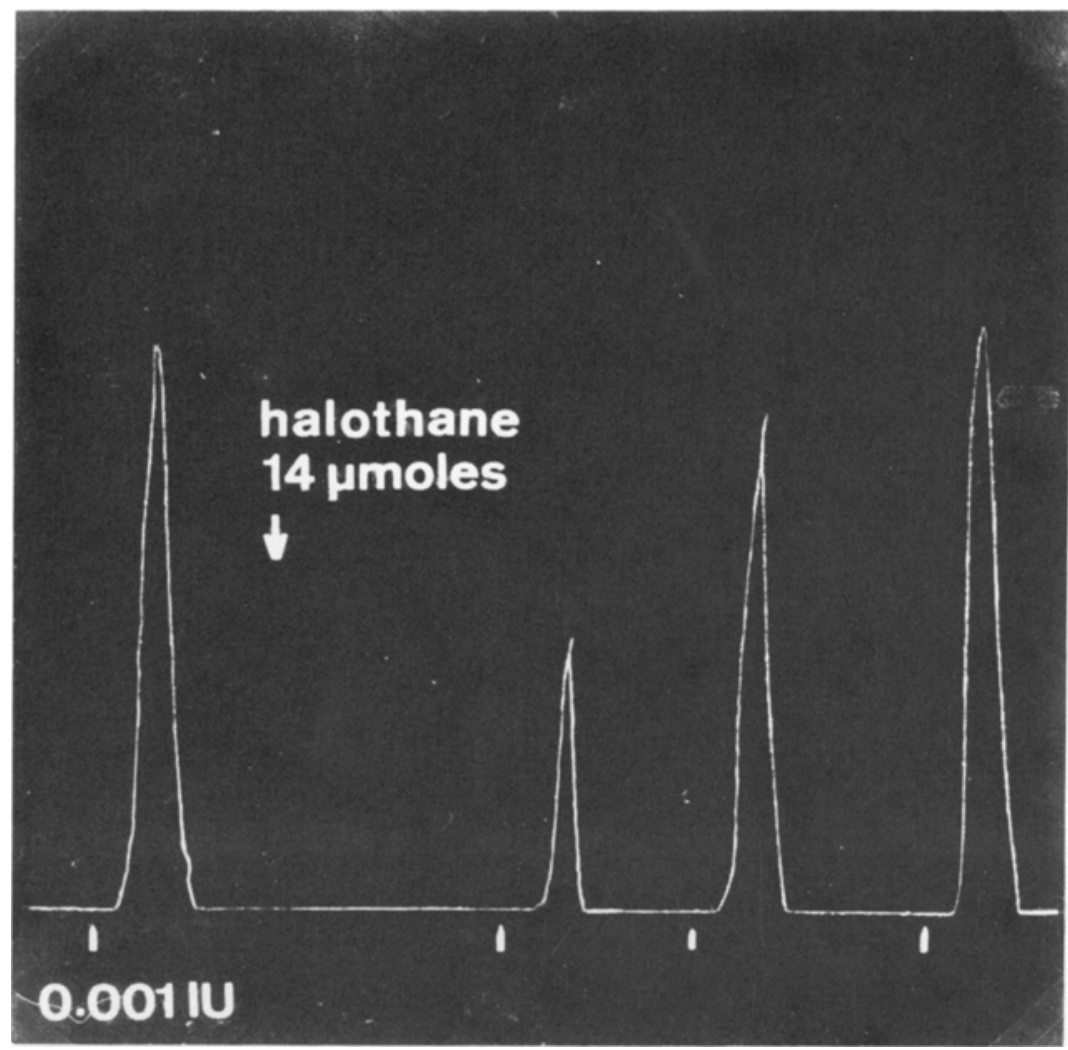

FIGURE 3. Effect of $14 \mu$ moles of halothane on rat uterus (nonoestrus) contractions stimulated by oxytocin $0.001 \mathrm{IU}$ (small arrows). Halothane was added one minute before oxytocin and the medium $(10 \mathrm{ml})$ was replaced after each contraction. The test proceeds from left to right.

relatively good muscle relaxation during surgical anaesthesia ${ }^{16,20,21}$ but only methoxyflurane, in low concentrations, has been suitable as an analgesic in obstetrics.

The concentration of methoxyflurane in venous blood during surgical anaesthesia is about $15 \mathrm{mg} / 100 \mathrm{ml}^{16}$ and during obstetrical analgesia up to $8.5 \mathrm{mg} / 100$ $\mathrm{ml}{ }^{12}$ may be reached. In the present in vitro study the addition of $0.9 \mu$ moles of methoxyflurane resulted in a concentration of $14 \mathrm{mg} / 100 \mathrm{ml}$ in the bath, which is well within the limits for surgical anaesthesia. Thus, the possibility exists that oxytocin given postpartum during methoxyflurane anaesthesia may be ineffective.

The effect of small doses of methoxyflurane on the rat uterus was probably not primarily due to anaesthesia, because the normal response to oxytocin was immediately restored upon replacing the medium following the inhibited contraction (Figure 1).

The inhibitory doses of halothane and especially those of fluroxene were much too high to be comparable to clinical conditions and oxytocics given postpartum therefore probably are not antagonized by these anaesthetics. 


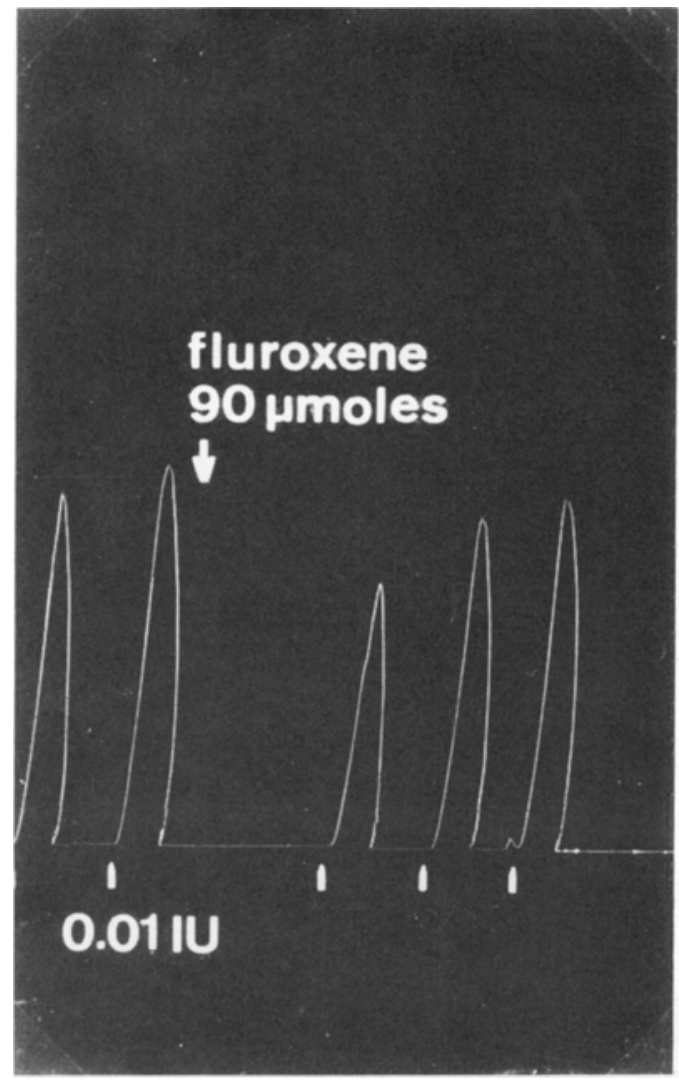

Figure 4. Effect of $90 \mu$ moles of fluroxene on rat uterus (nonoestrus) contractions stimulated by oxytocin 0.01 IU (small arrows). Fluroxene was added one minute before oxytocin and the medium ( $10 \mathrm{ml}$ ) was replaced after each contraction. The test proceeds from left to right.

The fact that there is a close relationship between the peptide molecules of oxytocin and those of vasopressin $(\mathrm{ADH})^{22}$ may indicate a similar relatively specific inhibition of vasopressin activity by methoxyflurane. It has, indeed, been suggested that blocking of the antidiuretic hormone or of its effector site in the renal tubules might be the mechanism of the polyuric syndrome related to methoxyflurane anaesthesia, ${ }^{4,6}$ although no significant effects on plasma vasopressin levels due to methoxyflurane anaesthesia have been observed..$^{23,24}$

\section{SUMMARY}

Methoxyflurane in doses comparable to clinical conditions caused in vitro significant inhibition of uterine contractions of the rat, stimulated by oxytocin. The uterine activity was restored when the medium surrounding the uterus was replaced suggesting a probable inactivation of the oxytocin molecule or blocking of receptor site by methoxyflurane. Oxytocin given postpartum in Caesarean sec- 
tions during methoxyflurane anaesthesia might therefore be only partially effective.

On the contrary, halothane and fluoroxene seem not to interfere with oxytocin activity, because toxic doses were needed to inhibit uterine contractions.

\section{RÉSUMÉ}

Le méthoxyflurane, à des doses comparables aux doses cliniques, a produit, in vitro, une inhibition importante des contractions utérines du rat, stimulées par l'oxytocine. L'activité utérine a été rétablie au moment où le voisinage de l'utérus a été remplacé, ce qui fait penser que le méthoxyflurane inactive probablement la molécule d'oxytocine ou bloque son récepteur. En conséquence, l'oxytocine que lon donne après la sortie de l'enfant au cours de la césarienne sous anesthésie au méthoxyflurane pourrait produire que des effets partiels.

Par contre, l'haolthane et le fluroxene ne semble pas modifier l'activité de l'oxytocine, car il a fallu donner des doses toxiques pour inhiber les contractions utérines.

\section{REFERENCES}

1. Linde, H.W., LAmb, V.E., Quimby, C.W., Homi, J., \& Eckenhoff, J.E. The search for better anesthetic agents: clinical investigation of Forane. Anesthesiology 32: 555 (1970).

2. Stevens, W.C. \& EGER, E.I. II. Comparative evaluation of new inhalation anesthetics. Anesthesiology 35: 125 (1971).

3. Vitcha, J.F. A history of Forane. Anesthesiology 35: 4 (1971).

4. Panner, B.J., Freeman, R.B., Roth-Moyo, L.A., \& Markowitch, W., Jr. Toxicity following methoxyflurane anesthesia. I. Clinical and pathological observations in two fatal cases. J.A.M.A. 214: 86 (1970).

5. Frascino, J.A., Vanamee, P., \& Rosen, P.P. Renal oxalosis and azotemia after methoxyflurane anesthesia. New England J. Med. 283: 676 (1970).

6. Mazze, R.I., Srrue, G.L., \& JACKson, S.H. Renal dysfunction associated with methoxyflurane anesthesia. A randomized, prospective clinical evaluation. J.A.M.A. 216: 278 (1971).

7. Elkington, S.G., Goffinet, J.A., \& Conn, H.O. Renal and hepatic injury associated with methoxyflurane anesthesia. Ann. Int. Med. 69: 1229 (1968).

8. Stefanini, M., Herland, A., \& Kosyax, E.P. Fatal massive necrosis of the liver after repeated exposure to methoxyflurane. Anesthesiology 32: 374 (1970).

9. Boisvert, M. \& Hudon, F. Clinical evaluation of methoxyflurane in obstetrical anaesthesia: a report on 500 cases. Canad. Anaesth. Soc. J. 9: 325 (1962).

10. Romagnoli, A. \& Korman, D. Methoxyflurane in obstetrical anaesthesia and analgesia. Canad. Anaesth. Soc. J. 9: 414 (1967).

11. Bodley, P.O., Mirza, V., Spears, I.R., \& Spilsbury, R.A. Obstetrical analgesia with methoxyflurane. Anaesthesia 21: 457 (1966).

12. Clark, R.B., Cooper, J.O., Brown, W.E., \& Greifenstern, F.E. The effect of methoxyflurane on the foetus. Brit. J. Anaesth. 42: 286 (1970).

13. Major, V., Rosen, M., \& Mushin, W.W. Concentration of methoxyflurane for obstetric analgesia by self-administered intermittent inhalation. Brit. Med. J. 4: 767 (1967).

14. Latto, I.P., Rosen, M., \& Molloy, M.J. Absence of accumulation of methoxyflurane during intermittent self-administration for pain relief in labour. Brit. J. Anaesth. 44: 391 (1972).

15. Rosen, M., Latto, I.P., \& Asscher, A.W. Kidney function after methoxyflurane analgesia during labour. Brit. Med. J. I: 81 (1972).

16. Hudon, F., Jacques, A., Clavet, M., Houde, J.-J., Pelletier, J., \& Traham, M. Symposium on methoxyflurane. Canad. Anaesth. Soc. J. 10:276 (1963). 
17. Albert, C.A., Anderson, G., Wallace, W., Henley, E.E., Winshel, A.W., \& Albert, S.N. Fluothane for obstetric anaesthesia. Obst. Gynec. 13: 282 (1959).

18. Crawford, J.S. The place of halothane in obstetrics. Brit. J. Anaesth. 34: 386 ( 1962 ).

19. Pharmacopoea Nordica, Editio Fennica. Vol. IV: Biological assay of oxytocin. Helsinki 1961.

20. Raventos, J, The action of fluothane - a new volatile anaesthetic. Brit. J. Pharmacol. 11: 394 (1956).

21. Martin, E.M. \& BosNax, J.N. Trifluoroethylvinyl ether (Fluroxene, Fluoromar 8 ) in obstetrics. Canad. Anaesth. Soc. J. 9: 419 (1962).

22. Guyton, A.C. Textbook of Medical Physiology, Philadelphia and London: W.B. Saunders $(1966)$.

23. Oyama, T. \& Sato, K. Plasma levels of antidiuretic hormone in man during methoxyflurane anesthesia and surgery. Anaesthesia 25: 500 (1970).

24. Oyama, T., Kmura, K., \& SAтo, K. Effect of methoxyflurane anaesthesia and surgery on plasma antidiuretic hormone ( $\mathrm{ADH}$ ) and renal function in man. Proceedings of $\mathrm{X}$ Scandinavian Congress of Anaesthesiologists, Lund 1971. 